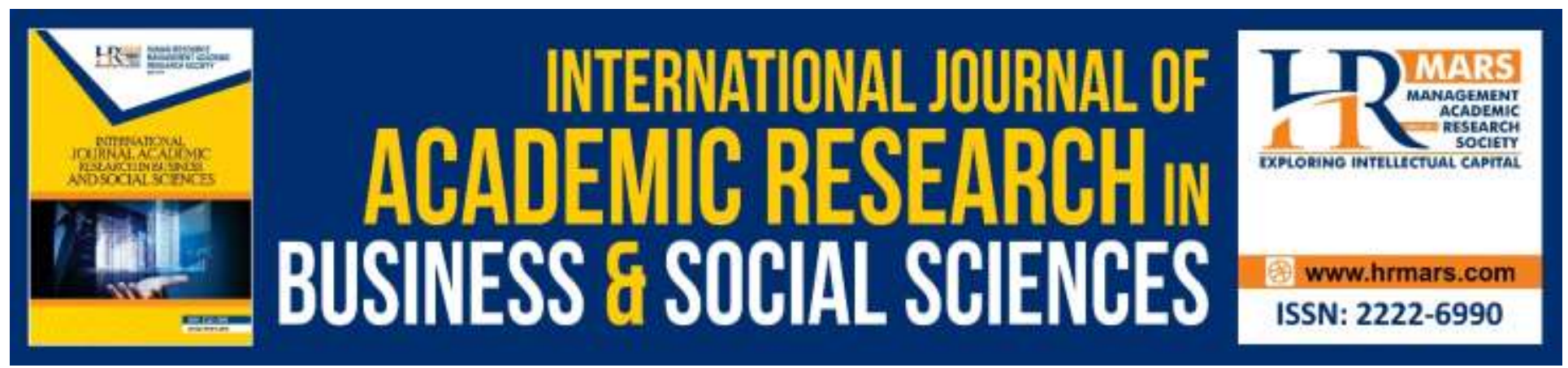

\title{
Drivers of Non-Participation in Environmental Impact Assessment (EIA) with Evidence to Malaysia's MRT Project
}

Fairiz Miza Yop Zain, Dasimah Omar, Mohamad Tajudin Saidin, Nor Suzila Lop

To Link this Article: http://dx.doi.org/10.6007/IJARBSS/v9-i11/6650

DOI: 10.6007/IJARBSS/v9-i11/6650

Received: 14 October 2019, Revised: 29 October 2019, Accepted: 07 November 2019

Published Online: 28 November 2019

In-Text Citation: (Zain, Omar, Saidin, \& Lop, 2019)

To Cite this Article: Zain, F. M. Y., Omar, D., Saidin, M. T., \& Lop, N. S. (2019). Drivers of Non-Participation in Environmental Impact Assessment (EIA) with Evidence to Malaysia's MRT Project. International Journal of Academic Research in Business and Social Sciences, 9(11), 1221-1227.

Copyright: (C) 2019 The Author(s)

Published by Human Resource Management Academic Research Society (www.hrmars.com)

This article is published under the Creative Commons Attribution (CC BY 4.0) license. Anyone may reproduce, distribute, translate and create derivative works of this article (for both commercial and non-commercial purposes), subject to full attribution to the original publication and authors. The full terms of this license may be seen

at: $\underline{\text { http://creativecommons.org/licences/by/4.0/legalcode }}$

Vol. 9, No. 11, 2019, Pg. 1221 - 1227

http://hrmars.com/index.php/pages/detail/IJARBSS

JOURNAL HOMEPAGE

Full Terms \& Conditions of access and use can be found at

http://hrmars.com/index.php/pages/detail/publication-ethics 


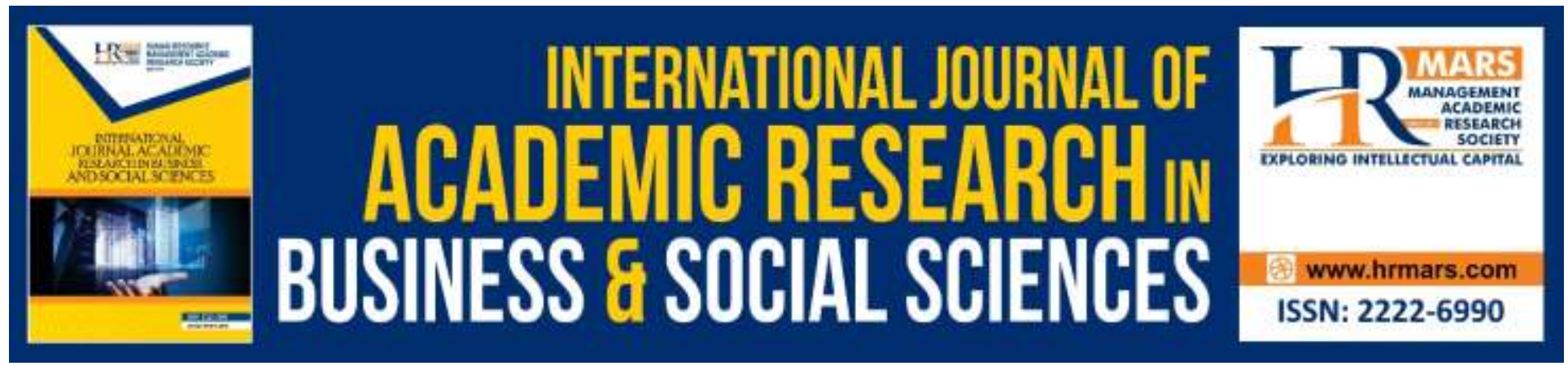

\title{
Drivers of Non-Participation in Environmental Impact Assessment (EIA) with Evidence to Malaysia's MRT Project
}

\author{
Fairiz Miza Yop Zain, Dasimah Omar, Mohamad Tajudin Saidin, \\ Nor Suzila Lop \\ Universiti Teknologi Mara, FSPU, Malaysia
}

\begin{abstract}
The big scale project always involves a large number of parties and stakeholder which might trigger a lot of issues. The study identified a level of public participation in Arnstein's ladder of participation and also identified several of issues of public participation. However, this paper focuses on the Non-participation of environmental impact assessment (EIA) process through eight rung of Arnstein's ladder of participation. The main objective of this study to identify the influencer of low level of public participation in Malaysia. The single case study has been used in this paper. This paper is also based on secondary data collection and primary data collection from qualitative method. The result of the study lead on the drivers of non-participation in EIA's public engagement for Malaysia's MRT project.

Keywords: Non-Participation, Public Participation, Environmental Impact Assessment (EIA), MRT, Malaysia

\section{Introduction}

The big scale project always involves a large number of parties and stakeholder which might trigger a lot of issues. In any propose development there are a clause of requirement to do the public participation and certain project are need to do environmental impact assessment. In a particular way, the EIA process is not just preparing a technical report but it has a requirement to have public engagement.
\end{abstract}

Public participation has been interpreted by some scholars as a mechanism to reduce the likelihood of conflict by ensuring representation of different interests and values, and by promoting transparency. (Baldizzone, 2014). 
Public participation is allowing the public to gain an understanding of government decisions and policies, while providing the government with input to help them design and implement a better and legitimate trade process. Effective public participation requires not only dialogue, but also the provision of relevant information and the allocation of adequate resources in advance. (Bastidas, 2014). While, the definitions of EIA are likely to be as a tool that to ensure the sustainability of development through the evaluation of impact to the proposed development that been handled by qualified person or organization. Azizan (2009) and Wasserman (2012)

\section{Non- Participation in Public Participation}

Public Participation meeting provides an opportunity to the public to express their own ideas Albayrak (2016). However, there is a critical difference between going through the empty ritual of participation and having the real power needed to affect the outcome of the process. (Arnstein, 1969). Author was highlights in her research on the fundamental point that participation without redistribution of power is an empty and frustrating process for the powerless. (Arnstein, 1969)

In Collins et al (2006) and Ayieola (2014) Arnstein's ladder first appeared in her 1969 paper (Arnstein, 1969) and set out to distinguish different levels of participation in relation to levels of, or access to, power. The simplicity of the ladder metaphor explains much of its appeal to a wide range of audiences: a graded movement upwards through 8 steps (rungs) from manipulation of citizens (Non-participation) (1) through consultation (Degree of Tokenism) (4) to citizen control (Citizen Power) (8).

Arnstein describes the type of "non-participation" represented by the lower two rungs on the ladder as attempts to 'educate' participants (Ayieola, 2014). Their real objective is not to enable people to participate in planning or conducting programs, but to enable power holders to "educate" or "cure" the participants (Arnstein, 1969). It means that the process is not democratic and also not people oriented. (Ayieola, 2014). Furthermore, in his research identified, majority of the respondents were not involved in the EIA process and this negate the guidelines as prescribe by the government agencies in Malaysia. The result implies of Malaysia's public participation for MRT is fall under "Non-participation"

\section{Issues and Challenge}

There are several issues regarding the public participation in EIA. Ahmad (2012) and Yaakob (2012) had mentioned on the barrier that could lead to the insufficient and ineffective participation is individuality attitude of human itself. In Glucker et al (2013) mentioned on poor of knowledge can become failure to have full range of potential contribution of input and output. Besides that, Not In My Backyard (NIMBY) Syndrome are clearly shows the attitude of public and also government agency or consultant (Alam, 2014; Cheryl, 2014). Furthermore, Dasimah \& oliver (2009) in their research are mentioned on poor execution of participation method can be 
considered as a failure to attract the public that could lead the low level of public involvement and also can create distrust towards authorities. (Aiyeola, 2014)

\section{Case Study and Methodology}

The single case study has been used in this paper. This paper is also based on secondary data collection such as journal, articles, books, and several online writing and primary data collection from qualitative method. A qualitative case study research was conducted with Executive environmental consultant and residents who willing to take part in this study of Malaysia's MRT project. The selected sample was purposive from Department of Environmental (DOE) Malaysia, consultant of EIA and resident along the line of MRT lane.

This study interviewed five respondents from executives of environmental and five respondents form public and the total interviewees were ten. The open-ended questions through semi structure interview was used as a tool for data collection. The tool of content analysis was used to analysis the collected data.

According to ERE consultant, 2011, the project involves the construction of a 51-km mass rapid transit line connecting Sungai Buloh to Kajang line (SBK) (Figure 2). The SBK line will pass through the Kuala Lumpur (KL) city centre and be integrated with the existing KTM Komuter, Ampang LRT Line and Kelana Jaya LRT Line. The SBK Line traverses under the jurisdiction of 5 local authorities Dewan Bandaraya Kuala Lumpur (DBKL), Majlis Perbandaran Kajang (MPKI), Majlis Bandaraya Shah Alam (MBSA) and Majlis Perbandaran Selayang (MPS).

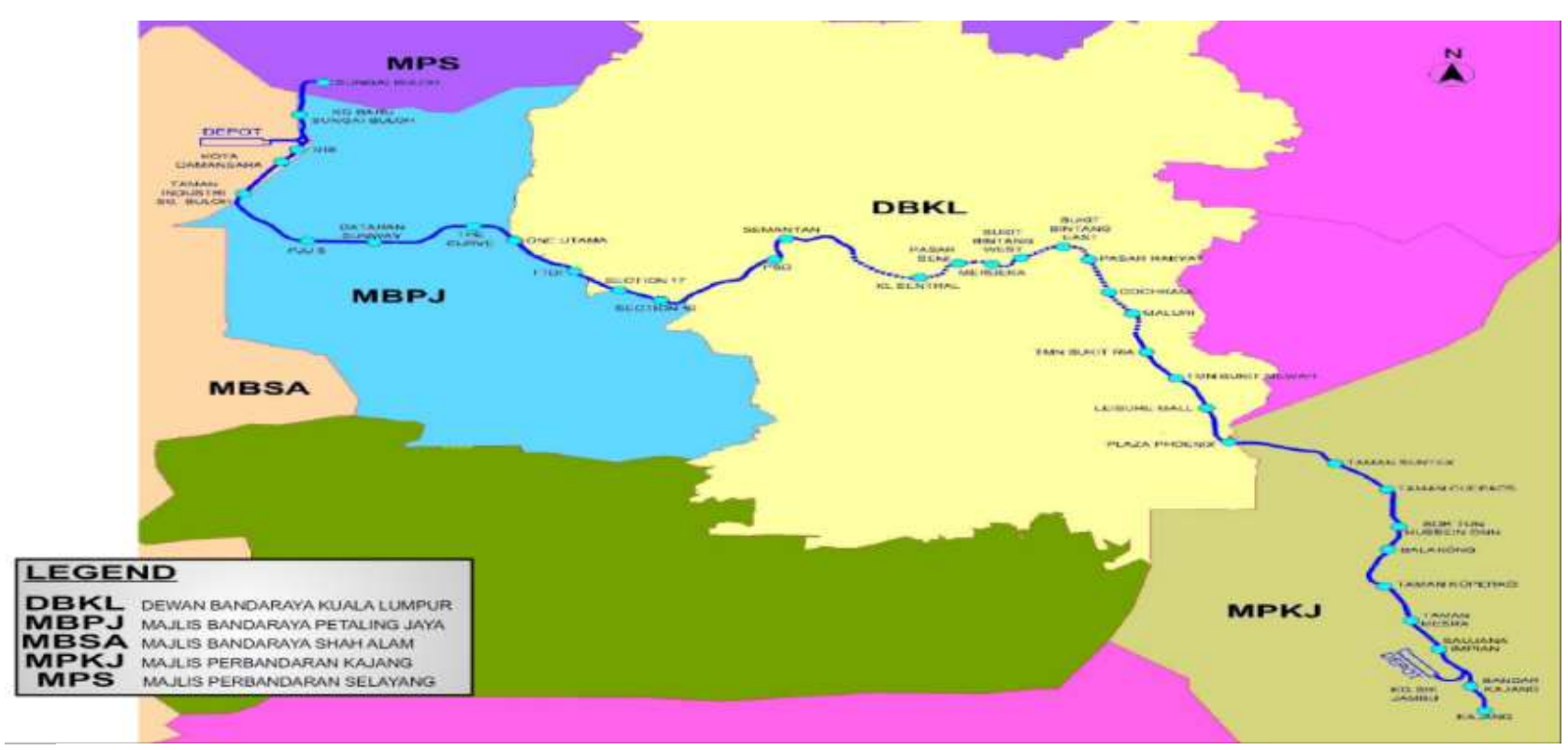

Figure 1: MRT Sungai Buloh-Kajang Line 


\section{Government Agencies Perspective}

Table 1, knowledge, behaviour, communication and marketing \& strategies were the main drivers to "Non-Participation" in public participation of EIA. First, the report and language are too technical where the public will have difficulty in understanding and this needs to be briefed beforehand. Secondly, NIMBY syndrome is likely a habit here. Thirdly, it hard to have comprehensive distribution information toward public and it also have limitation of information provided as Sarah (1996) mentioned sharing through participation does not necessarily means sharing in power. Lastly, marketing and strategy that had been conducted implies that it has lack of interesting notices and advertisements. These are all important factors that leads to Nonparticipation in EIA for the Malaysia's MRT project.

Table 1: Drivers of Non-Participation government Agencies Perspective

\begin{tabular}{l|ll}
\hline Items & Descriptions & Respondent \\
\hline Knowledge & $\begin{array}{l}\text { Technical report, public are not expertise and } \\
\text { need to be educate (about proposed A,B.C.D,E } \\
\text { development) }\end{array}$ & $\begin{array}{l}\text { NIMBY syndrome, easy to submit the report, A,B,C,D,E } \\
\text { public is not needed to involve }\end{array}$ \\
\hline Behavior & $\begin{array}{l}\text { Hard to have comprehensive information } \\
\text { distribution, some information is confidential A,B,E }\end{array}$ \\
\hline Communication and A, B,C \\
\hline $\begin{array}{l}\text { Marketing \& } \\
\text { strategies }\end{array}$ & $\begin{array}{l}\text { Not enough interesting notice and } \\
\text { advertisement s }\end{array}$ \\
\hline
\end{tabular}

\section{Public Perspective}

Table 2, main perception from public are also directly on knowledge, communication and marketing \& strategies. The public also realised that the lack of knowledge regarding the proposed development and technical report can be the main Non-participation factor. Referring to respondents there are less of two ways dialogue, besides that, they also mentioned on nothing can be contributed towards the project, meaning that nothing can be changed if they were to be involved. Lastly, most of the public have not noticed the advertisements and have no idea what is EIA and the process of it. These are all the important factors that leads to Non-participation in EIA for the Malaysia's MRT project. 
INTERNATIONAL JOURNAL OF ACADEMIC RESEARCH IN BUSINESS AND SOCIAL SCIENCES

Vol. 9, No. 11, November, 2019, E-ISSN: 2222-6990 @ 2019 HRMARS

Table 2: Drivers of Non-Participation Public Perspective

\begin{tabular}{l|ll}
\hline Items & Descriptions & Respondent \\
\hline Knowledge & $\begin{array}{l}\text { Lack of knowledge regarding the proposed } \\
\text { development and technical report }\end{array}$ & $1,2,3,4,5$ \\
\hline $\begin{array}{l}\text { Communicatio } \\
\mathrm{n}\end{array}$ & $\begin{array}{l}\text { Less of 2 ways dialogue, nothing can } \\
\text { contribute towards project (nothing change) }\end{array}$ & $1,2,3,4,5$ \\
\hline $\begin{array}{l}\text { Marketing \& } \\
\text { strategies }\end{array}$ & $\begin{array}{l}\text { Most public never notice the advertisement } \\
\text { and never know what is ElA and the process of 1,2,3,4,5 } \\
\text { public engagement }\end{array}$ \\
\hline
\end{tabular}

In sustainability of the environment and improving participation, it requires attitude reformation within the public as well as government's establishment and transparency in sharing information. Above all it requires both parties to play their part. (Aiyeola, 2014)

\section{Conclusion}

In conclusion, this study contributes to the main problems that could have different approaches from the government and government agencies to increase the level of public participation process in Malaysia. It is important to have relationship among the government organisations, private organisations, Non-Government Organisations, public and environment. The harmonisation among the stakeholder and environment is crucial for long term sustainability of the environment. Currently, almost all human being have self-awareness and conscious on environmental issues. However, their actions behind it does not represent their concern. Therefore, nowadays we have regulations and a system for the public participation in environmental impact assessment (EIA). However, there are rooms for improvement in achieving the quality of management, environment, relationship between governments, private, public and environment. Besides that, it may create awareness from the public for other matters besides of public participation in EIA and environmental issues. 
INTERNATIONAL JOURNAL OF ACADEMIC RESEARCH IN BUSINESS AND SOCIAL SCIENCES

Vol. 9, No. 11, November, 2019, E-ISSN: 2222-6990 ㄷ 2019 HRMARS

\section{References}

1- Rega, C. and Baldizzone, G. (2014) "Public Participation in Strategic Assessment: A Practitioners perspective." Environmental Impact Assessment Review 50 (2015):105115

2- Bastidas, S. (2004) "The Role of Public Participation In The impact Assessment of Trade Process" Speaker paper for the Impact Assessment for Industrial Development - IAIA'04 (April 28th 2004, Vancouver)

3- Marzuki, A. (2009) "A Review on Public Participation in Environmental Impact Assessment in Malaysia." Theoretical and Empirical Researches in Urban Management No. 3 (12)

4- Wasserman, C. (2012) "Application of Public Participation Principles in EIA," Strengthening Public Participation in Environmental Management in Indonesia Training Workshop, Jakarta, Indonesia.

5- Albayrak, A. (2016) "Public behaviour for public participation in EIA process, Turkey." IAIA16 Conference Proceedings Resilience and Sustainability 36th Annual Conference of the International Association for Impact Assessment (11 - 14 May 2016)

6- Arnstein, S. R. (1969) "A Ladder of Citizen Participation", Journal of the American Planning Association, 35: 4, $216-224$.

7- Collins, Kevin and Ison, R. (2006) “Dare we jump off Arnstein's ladder?” Social learning as a new policy paradigm. In: Proceedings of PATH (Participatory Approaches in Science \& Technology) Conference, 4-7 June 2006, Edinburgh.

8- Yaakob, H. (2012) "Penyertaan Awam: Kejayaan dan Kegagalan Dalam Perancangan Pembangunan." Journal Pengurusan Awam 67-84.

9- Alam, S. (2014) "Public Participation in the Enforcement of Environmental Laws: Issues and Challenges in the Light of the Legal and Regulatory Framework with Special Reference to EIAs in Malaysia" Bangladesh Research Foundation Journal Vol. 3, No. 1.

10- Cheryl, S. F., Chi, J. X., \& Xue, L. (2014) "Public participation in environmental impact assessment for public projects: a case of non-participation," Journal of Environmental Planning and Management, 57:9.

11- Omar, D., Leh, O. L. H. (2009) "Malaysia Development Planning System: Kuala Lumpur Structure Plan and Public participation", Asian Social Science Vol.5,No.3 pp.30-35.

12- Consulting ERE, (2011) "Klang Valley Mass Rapid Transit: Sungai Buloh- Kajang Line: Detailed Environmental Impact Assessment,' Malaysia.

13- White, S. (1996) "Depoliticising development: the uses and abuses of participation". Development in Practice. Vol. 6. 